\title{
MORINGA OLEIFERA AS A PHARMACEUTICAL EXCIPIENT
}

\author{
UPHADEK B. ${ }^{*}$, SHINKAR D. M., PATIL P. B., SAUDAGAR R. B. \\ Department of Pharmaceutics, R. G. Sapkal College of Pharmacy, Anjaneri 422213, Nasik, Maharashtra, India \\ Email: uphadekavita@gmail.com
}

Received: 26 Dec 2017, Revised and Accepted: 05 Feb 2018

\begin{abstract}
Plant gums and mucilages are being used due to their abundance in nature, safety and economy. Additives play an important role in pharmaceutical preparations like tablet, lotions, suspensions, syrups and ointments. Recent trends towards the use of the natural and nontoxic products which demand the replacement of synthetic excipients with natural ones. Moringaoleifera gum has good mucoadhesive polymer, disintegrating agent and binder. Moringa Oleiferagum show that it has high potential for industrial application especially in the food, textile and pharmaceutical industries.
\end{abstract}

Keywords: Gums, Mucilages, Additives, Mucoadhesive, Moringa Oleifera

(c) 2018 The Authors. Published by Innovare Academic Sciences Pvt Ltd. This is an open access article under the CC BY license (http://creativecommons.org/licenses/by/4.0/) DOI: http://dx.doi.org/10.22159/ijcpr.2018v10i2.25883

\section{INTRODUCTION [1-3]}

Nowdays Most of Researchers are trying to introduce new excipients for drug formulations to exhibit varied functions. The popularity of new excipient research is growing tremendously over the last few decades due to increasing demand for safe, economical and functionally reliable substitutes for the existing synthetic ones. There is almost all therapeutic formulations used for humans and others include excipients. Pharmaceutical excipients can be regarded as totally inert or inactive substance within the formulation, but are used to convert Active Pharmaceutical Ingredients into dosage forms suitable for administration to patient.

MoringaoleiferaLam belongs to family Moringaceae. It is also known as Drumstick in English, Saragvo in Gujarati, Soanj-na in Hindi, Sajna in Bengali, Nugge in Kannada, Sigru in Malyalam, Shevga in Marathi, Shobhanjana in Sanskrit and Munaga in Telugu. Moringa powder is sparingly soluble in water but swells in contact with water giving a highly viscous solution. In view of the easy availability of the plant, the ex-udates from the stem of the tree. The stem of the tree exudes a gum which is initially white in colour but changes to reddish brown to brownish black on exposure.

Moringa OleiferaLam. (Moringaceae) is one of the 14 species of the family moringaceae, native to India, Africa, Arabia, Southeast Asia, South America, and the Pacific and Caribbean Islands. Because M. oleiferahas been seen in many tropic and sub-tropic regions worldwide. The plant is referred to by a number of names such as horseradish tree, drumstick tree, ben oil tree, miracle tree, and "Mother's BestFriend". This plant grown and widely cultivated in the northern part of Nigeria and many countries in tropical Africa. Moeingaoleiferacanbe grown in a variety of soil conditions preferring well-drained sandy or loamy soilthat is slightly alkaline. Almost every part of M. oleiferacan be used for food and as aforage for livestock.

Moringa tree was introduced to Africa from India at the turn of the twentieth century where it was to be used as a health supplement. It is traditionally used for the treatment of a number of ailments including as fomentation to relieve spasm, diarrhea, as diuretic and stimulant in paralytic affliction, epilepsy ad hysteria. Study shows that, for centuriespeople in many countries have used Moringa leaves as traditional medicine forcommon ailments.

\section{Nutritional Importance [3-5]}

Moringa trees are very useful to combat malnutrition, especially among infants and nursing mothers. Three non-governmental organizations in particular-trees for Life, Church World Service and Educational Concerns for Hunger Organization-have advocated
Moringaas "natural nutrition for the tropics" Drumstick Leaves can be eaten fresh, cooked, or stored as dried powder for many months without refrigeration, and reportedly without loss of nutritional value. Moringais especially promising as a food source in the tropics because the tree is in full leafat the end of the dry season when other foods are typically scarce. A large number of reports on the nutritional qualities of Moringanow exist in both the scientific and the popularliterature. Moringa Oleiferacontain Vitamin A, calcium, iron, vitamin $\mathrm{C}$ and potassium respectively more than carrots, milk, spinach, oranges, and bananas. That the protein quality of Moringaleaves rivals that of milk and eggs. The leaves are rich in ironand therefore highly recommended for expectant mothers. Since allessential amino acids are present Moringa may be rightly called acomplete food for total nutrition.

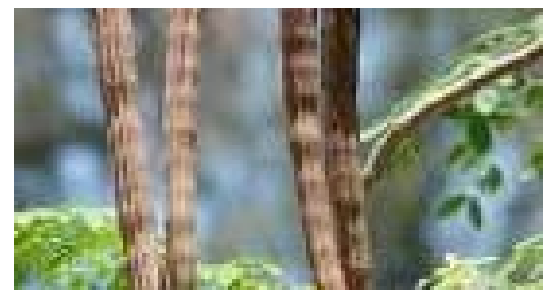

Fig. 1: Fruit of moringaoleifera

Pharmacological importance [3-11]

Analgesic activity

The experimental studies using hot plate and tail immersion method have shown thatalcoholic extract of leaves and seeds of Moringa oleifera possess marked analgesic activity and found to be equipotent to standard drug.

\section{Anti-inflammatory activity}

Poultice of leaves is beneficial in glandular swellings. The root extract exhibited significant anti-inflammatory activity in Carrageen induced rat paw edema.

\section{Antipyretic activity}

The antipyretic activity of ethanolic, petroleum ether, solvent ether and ethyl acetate extracts of seeds of moringa was screened using yeast induced hyperpyrexia method. 


\section{Wound healing properties}

Three wound models wiz excision wound, incision wound and dead space wound were selected for assessing wound healing activity of ethanolic and ethyl acetate extracts of leaves. Ethanolicand Ethyl acetate extracts ( $10 \% \mathrm{w} / \mathrm{w}$ extract in the form of ointment) showed significant wound healing activity that is comparable with the standard vicco turmeric cream, Phytosterols and phenolic compounds present in these extracts promote the wound healing activity.

Table 1: The nutrient composition of leaves, leaf powder, seeds and pods [1]

\begin{tabular}{|c|c|c|c|c|c|}
\hline Nutrients & Fresh leaves & Dry leaves & Leaf powder & Seed & Pods \\
\hline Calories (cal) & 92 & 329 & 205 & - & 25 \\
\hline Protein (g) & 6.7 & 29.4 & 27.1 & 35.97 & 2.5 \\
\hline Fat $(\mathrm{g})$ & 1.7 & 5.2 & 2.3 & 38.67 & 0.1 \\
\hline Carbohydrate (g) & 12.5 & 41.2 & 38.2 & 8.67 & 3.7 \\
\hline Fibre (g) & 0.9 & 12.5 & 19.2 & 2.87 & 4.8 \\
\hline Vitamin B1 (mg) & 0.06 & 2.02 & 2.64 & 0.05 & 0.05 \\
\hline Vitamin B2 (mg) & 0.05 & 21.3 & 20.5 & 0.06 & 0.07 \\
\hline Vitamin B3 (mg) & 0.8 & 7.6 & 8.2 & 0.2 & 0.2 \\
\hline Vitamin C (mg) & 220 & 15.8 & 17.3 & 4.5 & 120 \\
\hline Vitamin E (mg) & 448 & 10.8 & 113 & 751.67 & - \\
\hline Calcium (mg) & 440 & 2185 & 2003 & 45 & 30 \\
\hline Magnesium (mg) & 42 & 448 & 368 & 635 & 24 \\
\hline Phosphorus (mg) & 70 & 252 & 204 & 75 & 110 \\
\hline Potassium (mg) & 259 & 1236 & 1324 & - & 259 \\
\hline Copper (mg) & 0.07 & 0.49 & 0.57 & 5.20 & 3.1 \\
\hline Iron (mg) & 0.85 & 25.6 & 28.2 & - & 5.3 \\
\hline
\end{tabular}

All values are in $100 \mathrm{~g}$ per plant material

\section{Anti-asthmatic activity}

A study was carried out to investigate the efficacy and safety of seed kernels of Moringaoleiferain the treatment of bronchial asthma. The results showed an appreciable decrease in severity of symptoms of asthma and also simultaneous improvement in respiratory tract functions.

\section{Antidiabetic activity}

An extract from the Moringaleaves has been shown to be effective in lowering blood sugarlevels within $3 \mathrm{~h}$ ingestion, though less effectively than the standard hypoglycaemic drug.

\section{Hepatoprotective activity}

The methanolic and chloroform extracts of leaves of Moringaoleiferahave shownvery significant hepatoprotection against carbon tetrachloride induced hepatotoxicity in albino rats in reducingserum total bilirubin, direct bilirubin, Serum glutamic pyruvic transaminase, and serum glutamicoxaloacetic transaminase levels. Moringa roots have been reported to possess hepatoprotective activity. The aqueous and alcoholic extracts from Moringa flowers were also found as hepatoprotective effect, due to thepresence of quercetin, a well-known flavonoid.

\section{Antitumor and anticancer activity}

Some isolated bioactive compounds from the seeds of Moringaoleiferawere tested for antitumor promoting activity using 7, 12-dimethylbenzanthracene as initiator and 12-0-tetra-decanoylphorbol-13-acetate as tumour promoter. Niazimicin, a thiocarbamate from the leaves ofMoringaoleiferawas found to be a potent chemo preventive agent in chemical carcinogenesis. The seedextracts have also been found to be effective on hepatic carcinogen metabolizing enzymes, antioxidant parameters and skin papilloma genesis in mice. A seed ointment had similar effect to neomycin against Staphylococcus aureuspyodermain mice. It has been found that niazimicin exhibits inhibition of tumourpromoter induced Epstein-Barr virus activation.

\section{Antimicrobial activity}

Moringaroots are reported to be rich powerful antibacterial and antifungal effects. Theroot extract also showed antimicrobial property due to the presence of 4 alpha-L-rhamnosyloxybenzyl isothiocyanate. An aqueous extract made from seeds was found to be effective against P. aeruginosa, S. aureus and E. coli. An extract from leaves was found to beeffective at inhibiting the growth of fungi Basidiobolushaptosporus, B. ranarums and Spirochinfound in root,is effective against both Gram positive and Gram negative bacteria. M. oleiferaroot contains Anthonine wasfound highly toxic to the cholera bacterium. The antimicrobial activity of different Moringaoleiferaseedsextracts were tested against Scenedesmusobliquus(green algae), Escherichia coli, Pseudomonas aeruginosa, Staphylococcus aureus, Bacillussterothermophilus(bacterial strains) and Herpes Simplex virus type 1 (HSV 1) and Polio virus type 1 (sabinvaccine). Although, $\mathrm{P}$. aeruginosawas more resistant to all $\mathrm{M}$. oleifera extracts, $\mathrm{B}$. sterothermophiluswas moresensitive than other organisms to all extracts. The effect of aqueous methanolic extract and fixed oil on HSV1was highly similar, $52.22 \%$ and $45.20 \%$.

\section{Antihypertensive, diuretic and cholesterol lowering activities}

Moringa leaf juice is known to have astabilizing effect on blood pressure. Mustard oil glycosides and thiocarbamate glycosides have beenisolated from Moringaleaves which were found to be responsible for the blood pressure lowering effect. Moringaroots, leaves, flowers, gum and the aqueous infusion of seeds have been found to possess diureticactivity. Moringa leaves extract(crude) shows significant cholesterol lowering action in the bloodserum of high fat diet fed rats which might be attributed to the presence of a bioactive phytoconstituent i.e. $\beta$-sitosterol.

\section{Antispasmodic, Antiulcer and Anthelmintic activities}

Moringaroots and leaves have been reported topossess antispasmodic activity. This activity of leaves has been attributed to the presence of 4 alpha-Lrhamnosyloxy benzyl-o-methyl thiocarbamate possibly through calcium channel blocker. The spasmolyticactivity exhibited by different constituents provides pharmacological basis for traditional uses of this plant ingastrointestinal motility disorder. The methanolic extract of moringawas found to possess significant protectiveactions in acetylsalicylic acid; serotonin and indomethacin induced gastric lesions in experimental rats. Asignificant enhancement of the healing process in acetic acid-induced chronic gastric lesions was also observedwith the extract-treated animals. The flower and leaves also are considered to be of high medicinal value with antihelmenticacivity.

\section{In blindness and eye infections}

Though there are many causes of blindness, Vitamin A deficiency causesimpaired dark adaption and night blindness. Eating 
Moringaleaves, pods and leaf powder which contain highproportion of Vitamin A can help to prevent night blindness and eye problems in children. Ingesting drumstickleaves ( $\beta$-carotene and leutin) with oil helps in improving Vitamin A nutrition and perhaps delays the onset ofcataract. Also the juice can be instilled into eyes in cases of conjunctivitis.

\section{Cardiac and circulatory stimulant}

All parts of the tree are reported to be used as cardiac and circulatorystimulant. Moringinine acts on the sympathetic nervous system and acts as a cardiac stimulant.

\section{Antioxidant activity}

Antioxidant activity reported in oil from the dried seeds is higher than BHT (ButylatedHydroxy Toluene) and alpha-tocopherol. Aqueous methanol $(80 \%)$ and ethanol $(70 \%)$ extracts of freeze driedleaves showed radical scavenging and antioxidant activities. The drumstick leaves are found to be a greatsource of natural antioxidants.

\section{Antifertility activity}

The aqueous extract of root and bark at a dose of $200 \mathrm{mg} / \mathrm{kg}$ and $400 \mathrm{mg} / \mathrm{kg}$, respectivelyshowed post-coital anti fertility effect in rat and also induced foetalresorption at late pregnancy. Anaqueous extract of Moringaoleiferaroots was investigated for its estrogenic, anti-estrogenic, progestational andanti-progestational activities. Doses up to $600 \mathrm{mg} / \mathrm{kg}$ of the extract orally failed to induce a deciduas responsein the traumatized uterus of ovariectomized rats.

\section{Pharmaceutical application [2-3, 11-16]}

\section{Suspending agent}

A comparative study of gums of Moringaoleifera and tracaganth was reported. Zinc oxide suspensions were prepared with gum of Moringaoleifera and tracaganth. Their sedimentation profile, redispersibility, degree of flocculation and rheological behaviour were compared. The results shows that the suspending properties of Moringaoleiferagum are comparable with that of gum tragacanth.

\section{Surfactant behavior}

A study on interfacial properties and fluorescence of a coagulating protein extracted from Moringaseeds and its interaction with sodium dodecyl sulphate (SDS) was carried out. The study reported that

a) The protein extracted from Moring seeds has significant surfactant behavior.

b) The coagulant protein interacts strongly with SDS and the protein might have specific binding sites for SDS.

c) There is formation of protein-SDS complex.

\section{Film forming property}

Studies reported that gum of M. oleiferahas enormous potential for use in the preparation of polymeric films as drug delivery systems.

\section{As stabilizer}

Plant phenolics have gained considerable interest in recent years for their potential effects against food related microorganisms. Phenolic extract obtained from the leaves of M. oleifera and M. orusindica showed stabilizing activity. In the present study effect of addition of phenolic extract from leaves of M. oleiferaand M. indicaon the shelf life of pineapple juice stored at $40^{\circ} \mathrm{C}$ was investigated by monitoring the changes in titrableacidity and sensory parameters for $8 \mathrm{w}$. Results observed that the extracts of natural phenolics can be usedto improve the quality and safety of foods.

\section{Cosmetic use}

Various parts of Moringaoleifera have cosmetic value. Cognis Laboratories Serobiologics team developed Puricare TM and Purisoft TM, two active ingredients based on botanical peptides from the seeds of Moringaoleiferatree that purify hair and skin and offer protection against the effects of pollution. Moringaseed oil, known as Behen oil is widely used as a carrier oil in cosmetic preparations. The healing properties of Moringaoil were documented by ancient cultures. Moringaoil possesses exceptional oxidative stability whichmay explainwhy the Egyptians placed vases of Moringaoil in their tombs. It is high in oleic acid and similar incomposition to olive oil. Moringaoil is light and spreads easily on the skin. It is good oil for use in massage and aromatherapy applications. It can be used in body and hair care as a moisturizer and skin conditioner. Other usesinclude soap making and for use in cosmetic preparations such as lip balm and creams. Moringaoleiferabutter, a semisolid fraction of Moringaoil, is used in baby products to contribute a free radical resistant emollient with exceptionally long lasting skin soften.

\section{Detoxification/water purification}

Moringahas the ability to remove hazardous materials from water. After oilextraction of Moringaseeds the left press cake contains water soluble proteins that act as effective coagulantsfor water purification. The charged protein molecules can serveas nontoxic natural polypeptides to settlemineral particles and organics in the purification of drinking water, vegetable oil, depositing juice and beer. Moringaseeds showed similar coagulation effects to alum. It is also reported that a recombinant protein in theseed is able to flocculate gram positive and gram negative bacterial cells. Moringaseeds could be used as abiosorbant for the removal of cadmium from aqueous media. Thus water purifying attributes of Moringaseedsare as coagulant, microbial elimination and as a biosorbant.

\section{Binder}

In view of importance of binders in pharmaceuticals for the manufacture of tablets and capsules, gum extracted from the bark of Moringa Oleiferagum was evaluate its binding properties through assessment of various parameters essential for pharmaceutical formulation.

\section{Starch}

Starch is also one of the most widely used biomaterial in the food, textile, cosmetics, plastics, adhesives, paper and pharmaceutical industries. The diverseindustrial usage of starch is based on its availability at low cost, high calorific value and inherent excellent physicochemical properties. Theversatility of starch in industrial applications is clearly defined by its physicochemical properties; therefore, a thorough evaluation of the necessary parameters is important in elucidating its industrial uses. Moringa Oleiferastarch as a new starch feedstock for Industrial use which can reduce the burden on other starch sources such as cassava, corn, yam, potatoes and other complex carbohydrates. And also to provide an inherent nutritional benefits for various industrial products that use starch as one of the raw material.

\section{Disintegrant}

Moringaaleifera isolated gum powder can be effectively used as disintegrant. The disintegration time for natural gum was found to be less when comparedto synthetic gum tablet.

\section{Future potential [18-20]}

In coming decades, it is anticipated that natural polymers will be coming as additional derivatives for development of various novel drug delivery systems due to a number of actions such as coating agent, gel former, controlled-release matrix, in addition to inducing desirable properties such as mucoadhesion and permeation enhancement to improve oral bioavailability of a drug.

\section{CONCLUSION}

After survey of various literatures concluded that natural polymer like Moringaoleiferaplays a vital role inthe development of Novel drug delivery systems. So in future these polymers may be used widely by theresearcher for the development of NDDS because of its advantage over other synthetic polymer. We anticipate that more uses of natural polymer will be coming as additional derivatives are synthesized and newer formulations are developed. The natural polymers can serve a number of purposes, including as a coating 
agent, gel former, controlled-release matrix, in addition to inducing desirable properties, such as mucoadhesion and permeation enhancement to improve oral bioavailability of a drug.

\section{AUTHORS CONTRIBUTIONS}

All the author have contributed equally

\section{CONFLICT OF INTERESTS}

Declared none

\section{REFERENCES}

1. Dubey DK, Dora J, Gulsan AK, Gulsan RK. A multipurpose treeMoringaOleifera. Int J Pharm Chem Sci 2013;2:413-22.

2. Gopalakrishnan L, Doriya K, Kumar DS. MoringaOleifera: a review on nutritive importance and its medicinalapplication. Food Sci Human Wellness 2016;5:49-56.

3. Darekar AB, Kahane JU, Ashawat M, Chavan MJ, Saudagar RB. Plant exudates and mucilage as pharmaceutical excipients. J Adv Pharm Educ Res 2013;3:387-401.

4. Khathuriya R, Nayyar T, Sabharwal S, Jain UK, Taneja R. Recent approaches and pharmaceutical applications of natural polysaccharides: a review. Int J Pharm Sci Res 2015;6:4904-19.

5. Kaur L, Sharma J, Kanuja N. Natural polymers-promising potential in drug delivery. Int J PharmTech Res 2013;5:684-99.

6. Abitha MH, Flowerlet M. Natural polymers in pharmaceutical formulation. Int J Institutional Pharm Life Sci 2015;5:205-31.

7. Patel BV, Patel D. Study of disintegrant property of MoringaOleifera gum and its comparison with other superdisintegrants. Int J Chem Tech Res 2011;3:1119-24.

8. Panda D, Swain S, Kaungo SK, Gupta R. Preparation and evaluation of gels from gum of MoringaOleifera. Indian J Pharma Sci 2006;68:777-80.

9. Patel MT, Patel JK, Upadhyay UM. Assessment of various pharmaceutical excipient properties of natural MoringaOleifera gum. Int J Pharm Life Sci 2012;3:1833-47.
10. Choudhary PD, Pawar HA. Recently investigated natural gums and mucilages as pharmaceutical excipients: an overview. J Pharm 2014. http://dx.doi.org/10.1155/2014/204849

11. Shah DP, Jain VC, Dalvadi HP. A preliminary investigation of MoringaOleifera lam gum as a pharmaceutical excipient. Int J Pharm Res Technol 2011;1:12-6.

12. Aney JS, Tambe R, Kulkarni M, Bhise K. Pharmacological and pharmaceutical potential of moringaoleifera: a review. J Pharm Res 2009;2:1424-6.

13. CP Khare. Indian Medicinal Plants. An Illustrated Dictionary; 2007. p. 422-3.

14. Hukkeri VI, Nagathan CV, Karadi RV, Patil SV. Antipyretic and wound healing activities of moringaoleifera lam in rats. Indian J Pharm Sci 2006;68:124-6.

15. Agarwal B, Mehta A. Antiasthmatic activity of moringaoleiferalam: a clinical study. Indian J Pharmacol 2008;40:28-38.

16. Manjari M, Piyush M, Agarwal AC. Pharmacognostical and phytochemical investigation of antidiabetic activity of Moringaoleifera lamleaf. Indian Pharm 2007;6:70-2.

17. Pal SK, Mukherjee PK, Saha BP. Studies on antiulcer activity of Moringaoleifera leaf extracts on gastric ulcer models in rats. Phytother Res 1995;9:463-5.

18. Mehta LK, Balaraman R, Amin AH, Bafna PA, Gulati OD. Effect of fruits of Moringaoleifera on the lipid profile of normal and hypercholesterolaemic rabbits. J Ethnopharmacol 2003;86:191-5.

19. Shivalingam MR, Kumaran KSG, Reddy YVK, Jeslin D, SudhanaRao MT, Chaitanya BS. Evaluation of binding properties of Moringaoleifera gum in the formulation of paracetamol tablets. Drug Invention Today 2010;2:69-71.

20. Zheng Yi, Zhu Fan, Lin Dan. Optimization of formulation and processing of MoringaOleifera and spirulina complex tablets. Saudi J Biol Sci 2017;24:122-6. 